
Kyiv National University of Trade and Economics,

Kyiv, Ukraine

ORCID: 0000-0001-6626-4381

Researcher ID: N-7693-2016

Lebedeva Larysa,

$\mathrm{PhD}$ in Economics, Associate Professor, Kyiv National University of Trade and Economics, Kyiv, Ukraine ORCID: 0000-0001-8632-5460 Researcher ID: O-2213-2016

\title{
CHALLENGES FOR BUSINESS IN THE KNOWLEDGE ECONOMY
}

The article explores the challenges for business in today's knowledge economy. The challenges related to human-environment relations and sustainable economic development, problems of institutional constraints in the transition to the modern economy, behavioral aspects of the interaction between economic agents and the organization of economic relations in a new society are highlighted.

Keywords: knowledge economy, Ecological economics, Institutionalism, Behavioral economics, Evolutionary economics.

\section{Лагутін Василь, Лебедева Лариса. Виклики для бізнесу в економіці знанb. \\ У статті досліджені виклики для бізнесу в сучасній економіці знань.} Висвітлено проблеми, пов'язані з середовищем існування людини та сталим економічним розвитком, проблеми інституиійних обмежень при переході до сучасної економіки, поведінкові аспекти взаємодї економічних агентів та організаиії економічних відносин у новому суспільстві.

Ключові слова: економіка знань, екологічна економіка, інститучіоналізм, поведінкова економіка, еволюиійна економіка

Relevance of research topic. The knowledge economy of today is much different from the economy of the twentieth century. In the industrial era, the basis of development were material factors of production, such as land, capital, labor. Today, in the information and digital age, intangible factors and human knowledge and skills, 
that is, human capital, as a source of growth, are already playing a decisive role in business development. That is why the study of changes in the knowledge economy of the XXI century is relevant, as they are the environment for business development.

Formulation of the problem. At the present stage of economic development, business faces many problems. These problems are related to the organization of relations of post-industrial society, to the interaction between a man and nature and the impact of these processes on economic activity, to the institutional constraints of economic activity that arise in the process of transition to the knowledge economy, etc. These problems all need to be researched and covered. Therefore, this article will analyze the challenges for business entities related to the development of the $21 \mathrm{st}$ century knowledge economy.

Analysis of recent researches and publications. The research of the problems of the new knowledge economy, post-industrial society and the changes that it brings was made by: V. Heyets, A. Hrytsenko and others [8,9]. The problems and challenges of the present stage of economic development are considered in the works of: M. Common, R. Ayres, T. Jackson, A. Fanning, M. Malmaeus, I. Cosme, M. Weiss, T. Foxon and others $[1-5,10,11,13]$. However, many issues remain unsolved, and further research is needed especially in the field of new organization of post-industrial society's economic relations and the challenges it poses to the business environment.

Presenting main material. To date, there are following economic approaches that reveal the problems of development of knowledge economy:

First, research of an impact of environmental issues on economic development, disposal of hazardous wastes, a problem of economic development and human wellbeing (inequality in income distribution, poverty), an issue of sustainable development, problems of economic growth, state environmental policy, and others are covered by Ecological economics. Researchers dealing with these problems argue for the need to include the Ecological economics in the dominant economic paradigm [2]. For example, although the dominant theory of economic growth suggests that output growth depends on an increase in the number of workers and their productivity, capital and knowledge, modern researchers [1] argue that economic growth is better explained by so-called «useful work» as a factor of production. In today's economies, useful work depends largely on the availability of relatively cheap and high-quality energy. In addition, ecological analysis shows that the transition to a sustainable low carbon economy will demand the replacement of the goal of increasing economic growth as a key public policy objective to ensure environmental equilibrium and sustainable economic development [10]. Economists go even further in this matter and propose to shift to a modern state policy of low or zero growth $[11,3]$ and negative growth $[13,11]$ justifying their position by the notion that economic growth cannot be maintained indefinitely on a planet with a scarce resources. 
Second, Behavioral economics studies have shown in detail the limited rationality of people in making economic decisions and the dependence on other people's prejudices and behavior. For example, it is far more important for people to avoid losses at present than to get the potential benefits or minimize significant costs in the future. This type of behavior is not considered in the rational economic man model as either the prediction or at least the rational expectations that underlie most macroeconomic models.

Third, institutionalists emphasize on the crucial role played by institutions, including legal constraints and social norms in modern economies [12]. It is well known that lending to the US borrowers in purchase of housing that they were unable to continue to repay was one of the causes of the financial crisis of 2008-09, as securitization of these loans spread risks around the world. The fact that the role of banks and financial regulation is largely ignored in the macroeconomic models of the central bank may help to explain why these institutions are not sufficiently taken into account in economic policy-making.

Fourth, Evolutionary economists argue that technological and institutional changes in economic systems should be regarded as dynamic evolutionary processes. Thus, researchers should not try to explain these changes in terms of overall equilibrium [6]. This means that changes in the economy can be very situational, and require optimal public policy decisions, such as supporting innovation in the early stages of development.

The modern knowledge economy differs from the subject of economics no less than the economy of primitive or traditional society, because the results of production in it are exchanged neither by the law of marginal utility, nor by the law of value. Products of intellectual activity, including software products, are distributed today for one part at no cost and for another at differentiated prices, that depend on the seller's perception of the value of a product and social status of a buyer. On the one hand, there is a growing share of public goods distributed free of charge, and on the other hand, there are products of fashion brands that are sold at an exorbitant price that does not match the price of analogues or even better quality products. Products and services are becoming so diverse that it is simply not possible for a person to rationally compare them based on his objective needs and income.

The modern knowledge economy is a complex, adaptive, ever-changing system that differs significantly from the model analyzed within the neoclassical paradigm. In addition, changes in the economy related to the leading role of innovation and knowledge have a significant impact on the business environment and include the following:

- the modern knowledge economy is an open dynamic system, an unbalanced system. Modern economy as a living system evolving into a more complex system with various types of production and consumption that can rarely reach equilibrium. 
Moreover, in the process of evolution, it is increasingly moving away from this state, because its development is nonlinear, characterized by high turbulence. Therefore, since economics is a living system, the subject of economic science should be the study of the laws of its development and, accordingly, the mechanisms of its complexity and sustainability in the process of increasing the diversity of economic activity and its results;

- the modern knowledge economy is composed of heterogeneous economic entities that do not make optimal decisions but are able to learn and adapt over time;

- economic entities interact through different networks;

- macro models arise from the interaction of economic entities of the micro level, which in turn influence the construction of the macro models;

- information and knowledge change the production process, becoming one of its main factors.

Thus, the knowledge economy of today is an open dynamic system built on the network connections between economic entities that act in an adaptive way, combining limited economic resources.

Conclusion. The challenges for the business of today that relate to the formation and development of the modern economy include the following: challenges in human-environment relationships, sustainable economic development; problems of institutional constraints in the transition to the economy of today; behavioral aspects of the interaction between economic agents and the organization of economic relations in a new society.

\section{REFERENCES}

1. Ayres R., Jeroen C.J., Van den Bergh M., Lindenberger D., Warr B. (2013) The underestimated contribution of energy to economic growth. Structural Change and Economic Dynamics, 27, 79-88.

2. Common M., Stagl S. (2005) Ecological Economics: An Introduction. Cambridge University Press.

3. Cosme, I., Santos, R., and O’Neill, D.W. (2017) Assessing the degrowth discourse: A review and analysis of academic degrowth policy proposals. Journal of Cleaner Production, 149, 321-334. doi: 10.1016/j.jclepro.2017.02.016.

4. Fanning, A.L., O'Neill, D.W. (2019) The Wellbeing-Consumption paradox: Happiness, health, income, and carbon emissions in growing versus nongrowing economies. Journal of Cleaner Production, 212, 810-821. doi: 10.1016/j.jclepro.2018.11.223

5. Foxon T.J. (2013) Responding to the financial crisis: Need for a new economics. Environmental Innovation and Societal Transitions, 6, 126-128. 
6. Freeman C., Louca F. (2001). As times goes by. From the Industrial Revolutions to the Information Revolution. Oxford University Press. Cambridge.

7. Heikkinen T. (2015) (De)growth and welfare in an equilibrium model with heterogeneous consumers. Ecological Economics, 166, 330-340.

8. Heyets V. (2015) Polityko-ekonomichni zasady doslidzhennya suchasnoho suspilstva [Political and economic foundations of modern society research]. Ekonomichna teoriya, 3, 5-13 [in Ukrainian].

9. Hrytsenko A. (2015) Politychna ekonomiya rozdileno-spilnoho svitu: istoriya i suchasnist [Political economy of the divided-common world: history and present]. Ekonomichna teoriya, 3, 14-29 [in Ukrainian].

10. Jackson T., Victor P. (2012) Towards an Ecological Macroeconomics, INET Annual Plenary Conference: Paradigm Lost: rethinking economics and politics, Berlin. Retrieved from: https://www.ineteconomics.org/uploads/papers/victor-peterberlin-paper-draft-w-Tim-Jackson.pdf.

11. Malmaeus J. M., Alfredsson E. C. (2017) Potential Consequences on the Economy of Low or No Growth - Short and Long Term Perspectives. Ecological Economics, 134, 57-64.

12. North D. (1990) Institutions, Institutional Change and Economic Performance. Cambridge University Press.

13. Weiss M., Cattaneo C. (2017) Degrowth - Taking Stock and Reviewing an Emerging Academic Paradigm. Ecological Economics,137, 220-230. 